\title{
STATUS OF INSECTIVOROUS PLANTS IN NORTHEAST INDIA
}

Praveen Kumar Verma - Shifting Cultivation Division • Rain Forest Research Institute - Sotai Ali • Deovan • Post Box \# 136・Jorhat 785001 (Assam)・India・pkverma_bryo@yahoo.co.in JAN SCHLAUER • Zwischenstr. 11・60594 Frankfurt/Main•Germany• jan@carnivorousplants.org KRISHNA KUMAR RAWAT - CSIR-National Botanical Research Institute - Rana Pratap Marg • Lucknow -226 001 (U.P) ・ India

KRISHNA GIRI • Shifting Cultivation Division • Rain Forest Research Institute • Sotai Ali • Deovan • Post Box \#136• Jorhat 785001 (Assam) • India

Keywords: Biogeography, India, diversity, Red List data.

Introduction

There are approximately 700 identified species of carnivorous plants placed in 15 genera of nine families of dicotyledonous plants (Albert et al. 1992; Ellison \& Gotellli 2001; Fleischmann 2012; Rice 2006) (Table 1).

In India, a total of five genera of carnivorous plants are reported with 44 species; viz. Utricularia (38 species), Drosera (3), Nepenthes (1), Pinguicula (1), and Aldrovanda (1) (Santapau \& Henry 1976; Anonymous 1988; Singh \& Sanjappa 2011; Zaman et al. 2011; Kamble et al. 2012). Interestingly, northeastern India is the home of all five insectivorous genera, namely Nepenthes (commonly known as tropical pitcher plant), Drosera (sundew), Utricularia (bladderwort), Aldrovanda (waterwheel plant), and Pinguicula (butterwort) with a total of 21 species. The area also hosts the "ancestral false carnivorous" plant Plumbago zelayanica, often known as murderous plant.

\section{Climate}

Lowland to mid-altitude areas are characterized by subtropical climate (Table 2) with maximum temperatures and maximum precipitation (monsoon) in summer, i.e., May to September (in some places the highest temperatures are reached already in April), and average temperatures usually not dropping below $0^{\circ} \mathrm{C}$ in winter. As usual average temperatures decrease with increasing elevation, and in highlands, a mountain/alpine climate prevails. In Sikkim and Arunachal Pradesh, the tree line ranges from $5500 \mathrm{~m}$ in the north to $4000 \mathrm{~m}$ in the south, and the snow line ranges from $6100 \mathrm{~m}$ in the north to $4900 \mathrm{~m}$ in the south.

\section{Chorology}

The extreme northeast of India (Sikkim, Darjeeling - the northern part of West Bengal, Arunachal Pradesh, Assam, Meghalaya, Nagaland, Manipur, Tripura, Mizoram) is one of the most floristically most diverse places in Asia as it is located in the contact zone between the temperate flora from high elevations (Himalaya), the tropical flora from lowland peninsular India and Burma, and the subtropical flora from Yunnan, China. To the west it shares a border with Nepal, to the north with Bhutan, and China (Tibet), to the east with Burma (Myanmar) and to the south with Bangladesh. Covering less than $275,000 \mathrm{~km}^{2}$, it is composed of six different floristic provinces in four 


\begin{tabular}{|c|c|c|c|c|c|}
\hline \multirow[t]{2}{*}{ Order } & \multirow[t]{2}{*}{ Family } & \multirow[t]{2}{*}{ Genus } & \multicolumn{3}{|c|}{ Number of described species } \\
\hline & & & World & India & NE India \\
\hline Oxalidales & Cephalotaceae & Cephalotus & 1 & & \\
\hline \multirow{6}{*}{$\begin{array}{l}\text { Nepenthales } \\
\text { (Caryophyllales } \\
\text { s. lat.) }\end{array}$} & \multirow[t]{3}{*}{ Droseraceae } & Drosera & 168 & 3 & 2 \\
\hline & & Aldrovanda & 1 & 1 & 1 \\
\hline & & Dionaea & 1 & & \\
\hline & Drosophyllaceae & Drosophyllum & 1 & & \\
\hline & Nepenthaceae & Nepenthes & 127 & 1 & 1 \\
\hline & Dioncophyllaceae & Triphyophyllum & 1 & & \\
\hline \multirow[t]{4}{*}{ Ericales } & \multirow[t]{3}{*}{ Sarraceniaceae } & Darlingtonia & 1 & & \\
\hline & & Heliamphora & 20 & & \\
\hline & & Sarracenia & 8 & & \\
\hline & Roridulaceae & Roridula & 2 & & \\
\hline \multirow{4}{*}{$\begin{array}{l}\text { Scrophulariales } \\
\text { (Lamiales) }\end{array}$} & Byblidaceae & Byblis & 7 & & \\
\hline & \multirow[t]{3}{*}{ Lentibulariaceae } & Pinguicula & 94 & 1 & 1 \\
\hline & & Genlisea & 27 & & \\
\hline & & Utricularia & 234 & 38 & 16 \\
\hline Total & & & 693 & 44 & 21 \\
\hline
\end{tabular}

Regions according to Takhtajan's (1986) scheme: the Northern Burmese, Eastern Himalayan, and Khasi-Maipur Provinces belonging to the Eastern Asiatic Region, the Tibetan Province belonging to the Irano-Turanian Region, the Bengal Province belonging to the Indian Region, and the Southern Burmese Province belonging to the Indochinese Region. Any area of comparable size and latitudinal extension (between $22^{\circ} \mathrm{N}$ and $30^{\circ} \mathrm{N}$ ) in the New World or in Africa would cover at the most three Provinces in at the most two Regions. This extraordinary diversity is mainly due to the unique topographical profile, ranging from almost sea level in the Brahmaputra valley to $8598 \mathrm{~m}$ elevation (Kangchenjunga) at the Nepal border.

Pinguicula alpina (arctic + alpine + Himalayan) belongs to the temperate element. The paleotropical element is represented by Nepenthes khasiana. Its entire range is contained in the area of concern and is located north of the Tropic of Cancer, i.e., this is the only species in the genus Nepenthes naturally occurring outside the tropics. Drosera peltata is widespread in eastern Asia, Australia, and Oceania (Gibson et al. 2012, as D. lunata). It is the only tuber forming sundew to reach beyond the Australian diversification center of this group. Drosera burmannii is widespread in the Australasian tropics. While it is disputed whether its only record from Africa (Sierra Leone) is native there, another, closely related species (D. sessilifolia) is its neotropical counterpart. The tropical bladderworts in the area are the terrestrial Utricularia hirta, U. pubescens, U. caerulea, $U$. bifida, U. recta (syn. U. scandens subsp. firmula), U. foveolata, U. subulata, and the aquatic $U$. aurea, U. stellaris, and $U$. inflexa, all of which are more or less widespread in tropical eastern Asia 


\begin{tabular}{|c|c|c|c|}
\hline \multirow{2}{*}{$\begin{array}{l}\text { Location; State; } \\
\text { Elevation }\end{array}$} & \multirow{2}{*}{$\begin{array}{l}\text { Climate } \\
\text { Class }\end{array}$} & Precipitation & Temperature \\
\hline & & Annual/Monthly & Summer / Winter \\
\hline $\begin{array}{l}\text { Aizawl; Mizoram; } \\
1132 \text { m }\end{array}$ & \multirow{5}{*}{$\begin{array}{l}\text { Humid } \\
\text { Subtropical } \\
\text { (Cwa) }\end{array}$} & $\begin{array}{l}2200 \text { mm / } 6 \text { mm (Jan.) - } \\
305 \text { mm (Aug.) }\end{array}$ & $\begin{array}{c}18-27^{\circ} \mathrm{C}(\max .: \text { Apr. }) / \\
25-11^{\circ} \mathrm{C}\end{array}$ \\
\hline $\begin{array}{l}\text { Agartala; Tripura; } \\
13 \mathrm{~m}\end{array}$ & & $\begin{array}{c}2200 \mathrm{~mm} / 8 \mathrm{~mm} \text { (Dec.) - } \\
455 \mathrm{~mm} \text { (Jun.) }\end{array}$ & $\begin{array}{c}24-34^{\circ} \mathrm{C}(\max .: \text { Apr. }) / \\
33-10^{\circ} \mathrm{C}\end{array}$ \\
\hline $\begin{array}{l}\text { Guwahati; Assam; } \\
55 \text { m }\end{array}$ & & $\begin{array}{c}1700 \mathrm{~mm} / 7 \mathrm{~mm} \text { (Dec.) - } \\
345 \mathrm{~mm} \text { (Jul.) }\end{array}$ & $22-32^{\circ} \mathrm{C} / 30-10^{\circ} \mathrm{C}$ \\
\hline $\begin{array}{l}\text { Imphal; Manipur; } \\
790 \text { m }\end{array}$ & & $\begin{array}{c}1400 \mathrm{~mm} / 12 \mathrm{~mm} \text { (Jan.) - } \\
225 \mathrm{~mm} \text { (Jun.) }\end{array}$ & $15-33^{\circ} \mathrm{C} / 30-11^{\circ} \mathrm{C}$ \\
\hline $\begin{array}{l}\text { Kohima; Nagaland; } \\
1450 \mathrm{~m}\end{array}$ & & $\begin{array}{c}1800 \mathrm{~mm} / 8 \mathrm{~mm} \text { (Dec.) - } \\
370 \mathrm{~mm} \text { (Jul.) }\end{array}$ & $17-25^{\circ} \mathrm{C} / 23-5^{\circ} \mathrm{C}$ \\
\hline $\begin{array}{l}\text { Shillong; Meghalaya; } \\
1500 \mathrm{~m}\end{array}$ & \multirow{4}{*}{$\begin{array}{l}\text { Subtropical- } \\
\text { Highland } \\
(\mathrm{Cwb})\end{array}$} & $\begin{array}{c}2200 \mathrm{~mm} / 9 \mathrm{~mm} \text { (Dec.) - } \\
470 \mathrm{~mm} \text { (Jun.) }\end{array}$ & $15-24^{\circ} \mathrm{C} / 23-4^{\circ} \mathrm{C}$ \\
\hline $\begin{array}{l}\text { Itanagar; Arunachal } \\
\text { Pradesh; } 750 \mathrm{~m}\end{array}$ & & $\begin{array}{c}2300 \mathrm{~mm} / 15 \mathrm{~mm} \text { (Nov.) - } \\
510 \mathrm{~mm} \text { (Jul.) }\end{array}$ & $18-34^{\circ} \mathrm{C} / 18-8^{\circ} \mathrm{C}$ \\
\hline $\begin{array}{l}\text { Darjeeling; N West } \\
\text { Bengal; } 2050 \mathrm{~m}\end{array}$ & & $\begin{array}{c}3000 \mathrm{~mm} / 7 \mathrm{~mm} \text { (Dec.) - } \\
780 \mathrm{~mm} \text { (Jul.) }\end{array}$ & $11-20^{\circ} \mathrm{C} / 14-2^{\circ} \mathrm{C}$ \\
\hline $\begin{array}{l}\text { Gangtok; Sikkim; } \\
1700 \text { m }\end{array}$ & & $\begin{array}{c}3600 \mathrm{~mm} / 23 \mathrm{~mm} \text { (Dec.) - } \\
650 \mathrm{~mm} \text { (Jul.) }\end{array}$ & $13-22^{\circ} \mathrm{C} / 18-4^{\circ} \mathrm{C}$ \\
\hline
\end{tabular}

and many spread to tropical Africa and Australia, while only U. pubescens and U. subulata are also found in the Americas.

Utricularia. gibba and Aldrovanda vesiculosa represent azonal aquatics not closely tied to any climatic vegetation zone.

An exceptionally large number of species of the subtropical to tropical section Phyllaria of Utricularia (U. furcellata, U. christopheri, U. brachiata, U. striatula, U. multicaulis) are native or even endemic to this area. Utricularia kumaonensis, U. salwinensis, and U. forrestii, likewise members of this section, are known from the Salween-Irrawaddy divide in westernmost Yunnan, China/northernmost Burma, i.e., within some $200 \mathrm{~km}$ to the east of the area treated here. As all three species do also occur in the immediate vicinity to the north (Nepal, Bhutan, Tibet), it is quite probable that they occur in Himalayan northeastern India although no specimens have apparently been collected from here so far.

Other species presently not recorded from the area but known from surrounding territories are: Drosera indica (paleotropical, including. West Bengal, $c f$. Basak 1975, China [Yunnan], Burma); Utricularia capillacea (syn. U. scandens, paleotropical, including. Bihar, Nepal, China [Tibet, Yunnan], Burma, Bangladesh);

U. graminifolia (tropical East Asian, including, China [Yunnan], Burma);

U. uliginosa (tropical East Asian, including, China [Yunnan], Burma);

U. australis (azonal, widespread in the Old World, including, Nepal, Bhutan, China [Tibet, Yunnan], Burma);

U. minor (circumboreal, including, Nepal, Bhutan, China [Tibet, Yunnan], Burma). 
The majority (some 20) of the remaining Indian bladderwort species not known from the extreme northeast are members of $U$. section Oligocista and are more or less restricted to the Deccan peninsula, predominantly in the Western Ghats (Janarthanam \& Henry 1992; Taylor 1989).

\section{Conservation Status}

1. Nepenthes khasiana Hook. f.: Popularly known as tropical pitcher plants or monkey cups, Nepenthes khasiana belongs to the monotypic family Nepenthaceae with 127 natural and hybrid species across the world (Jebb \& Cheek 1997; Wikipedia 2013). It is the only native Indian species of insectivorous plant which is an endemic of Garo, Khasi, and Jaintia hills of Meghalaya. It greatly varies in its habit ranging from prostrate to scandent or rarely erect herbs, undershrubs, or shrubs. The plants are mostly associated with the natural vegetation of very humid climates.

Distribution in northeast India: Endemic to Meghalaya: East Khasi hills, West Khasi hills, Jaintia hills, south Garo hills, west Garo hills (Joseph \& Joseph 1986; Venugopal \& Devi 2003; Singh et al. 2011).

Present status: Habitat destruction is one of the main threats especially in Jaintia and Garo hills, where the coal mining plays a significance role in the decline of its natural population (Prasad \& Jeeva 2009; Singh et al. 2011). Excessive collection, developmental activities, deforestation, fragmentation, increasing production of waste and pollutants, forest fire, jhum cultivation, and poor seed germination ability of the plant are also some of the causes of declining populations (Bordoloi 1977; Jain \& Sastry 1980; Rathore et al. 1991; Mandal \& Mukherjee 2011). It is classified as 'Endangered' (EN) and is incorporated in the Appendix I of CITES and Negative List of Exports of the Government of India (Ziemer 2010; Mandal \& Mukherjee 2011). The species is restricted only in some pockets of Meghalaya.

2. Drosera L.: One of the largest genera of carnivorous plants (commonly known as sundews) with more than 160 species belonging to the family Droseraceae (Rice 2006; Jayaram \& Prasad 2006).

2.1. Drosera burmannii Vahl: One of the most common insectivorous species among Indian carnivorous plants and found in tropical and subtropical parts of the country. This annual species possess spatulate leaves and forms rosettes which spans up to $2.5 \mathrm{~cm}$. This species has important medicinal properties as it contains several medicinally active compounds including quinones (plumbagin), hydroplumbagin glucoside, flavonoids (kaempferol, myricetin, quercetin, and hyperoside), rossoliside (7-methyl-hydrojuglone-4-glucoside), and has been used for several disorders (Raju \& Christina 2013).

Distribution: Arunachal Pradesh, Assam, Meghalaya, Sikkim, Tripura (Majumdar et al. 2011).

Present status: Least concerned (LC) ver.3.1, IUCN, 2011 (Zhuang 2011a). The species has a wide range of distribution and no current threats are reported for Indian populations.

2.2 Drosera peltata Thunb. (syn. Drosera lunata Buch.-Ham. ex DC.): This is a climbing or scrambling sundew species commonly called shield sundew. The species possesses cauline or peltate cauline leaves and can be easily identified in the field with its aerial parts growing from 5 to $15 \mathrm{~cm}$ in height. The species is a promising medicinal plant species due to its antimicrobial activity particularly against the oral bacteria (Didry et al. 1998).

Distribution in northeast India: Meghalaya (Jantia hills, east and west Khasi hills), (Venugopal et al. 2007). 
Present status: The species is somewhat rare and known only in some areas of Meghalaya growing on expose rocks in association with mosses.

3. Utricularia L.: Another large genus of carnivorous plants with more than 230 species, which belongs to the family Lentibulariaceae (Parnell 2005; Fleischmann 2012) and commonly grows in floating as well as marshy lands. Unlike the other carnivorous plants discussed here, Utricularia often lives in aquatic conditions. A total of 16 species are found in northeastern India.

3.1. Utricularia aurea Lour.: Commonly known as golden bladderwort and is common in marshy and wet land of the area. Another important plant with compounds showing anti-tumor activity have been reported (Choosawad et al. 2005).

Distribution in northeast India: Assam (Sharma 2012, as Utricularia flexuosa Vahl.), Tripura (Bhowmik \& Datta 2013).

Present status: The IUCN, 2103 listed the species under Least Concern (LC) ver 3.1 (IUCN 2013).

3.2. Utricularia bifida L.: The small and annual plants are found growing in marshy land as well as damp soil and commonly known as bifid bladderwort.

Distribution in northeast India: Assam, Meghalaya, Tripura (Bhowmik \& Datta 2012a, 2013).

Present status: No major threats has been reported regionally as well as globally hence it been identified and is therefore listed as Least Concern (LC) 3.1. (Zhuang 2011b).

3.3. Utricularia brachiata Oliv.: Discovered by J.D. Hooker from Sikkim Himalaya and partially described by D. Oliver in 1859 . The plants are very small, inconspicuous, with delicate, reniform leaves and grow as epiphyte intermixed with bryophytes on tree trunks (Compton 1909).

Distribution in northeast India: Arunachal Pradesh, Sikkim- Kyongnosla Alpine Sanctuary (Compton 1909; Taylor 1989).

Present status: In northeast India the species is very rare and restricted only to the upper hills of eastern Himalaya with in rather small populations.

3.4. Utricularia caerulea L.: Small to medium sized species commonly known as blue bladderwort (Kato et al. 2006; Kamble et al. 2012).

Distribution in northeast India: Meghalaya, Tripura (Bhowmik \& Datta 2012b).

Present status: Very common in distribution and found from Madagascar to Japan and Australia through India and Malaysia (Kamble et al. 2012).

3.5. Utricularia christopheri P.Taylor: Perennial in nature.

Distribution in northeast India: Confined to East Himalayan region including Nepal; SikkimChangu, Lachen (Taylor 1989).

Present status: Grows in very high elevation in Sikkim Himalaya and Nepal with very limited distribution (Taylor 1989).

3.6. Utricularia gibba L.: A perennial aquatic herb commonly known as humped bladderwort. May be floating, growing submerged, or exposed on wet soil. One of the most common species among Utricularia (Taylor 1989).

Distribution in northeast India: Meghalaya (as U. khasiana Joseph \& Mani), Tripura (as U. gibba subsp. exoleta (R. Br.) P.Taylor) (Deb 1983; Bhowmik \& Datta 2013), Assam and Manipur (as U. 
exoleta R. Br.) (Dixit \& Bera 2012; Hazarika \& Borthakur 2012).

Present status: Least Concern (LC) ver 3.1 (Anitha 2011).

3.7. Utricularia foveolata Edgew.: A small short-lived herb growing in shallow water or wet soil in seasonally wet grassland or occasionally as a weed in ricefields.

Distribution in northeast India: Meghalaya: Elephant Falls as U. baouleensis A. Chev. (Subramanyam \& Kamble 1968).

Present status: Very rare in occurrence as it has been reported only once from Elephant Falls of Meghalaya in 1968 and no further reports are available from this area. Hence more detailed surveys are necessary to reveal its current status in India.

3.8. Utricularia furcellata Oliv.: Grows on moist logs or rocks along with mosses and form $3-5$ mm wide rosettes.

Distribution in northeast India: Assam, Meghalaya, Mizoram, West Bengal (Suksathan \& Parnell 2010; Chew \& Haron 2011; Panday et al. 2013; Yee et al. 2012).

Present status: The status is yet to be worked out; however, recently it has been considered as rare in Mizoram (Panday et al. 2013).

3.9. Utricularia hirta J.G.Klein ex Link.: A small perennial, terrestrial insectivorous plant, native of Southeast Asia, and always growing in damp open places.

Distribution in northeast India: Meghalaya (Joseph \& Mani 1982, as U. tayloriana J.Joseph \& J.Mani), Tripura (Joseph \& Mani 1982; Natarajan et al. 2008).

Present status: Least Concern (LC) ver 3.1 (Anitha 2011).

3.10. Utricularia multicaulis Oliv.: Very small growing annually and native of Southeast Asia. Distribution in northeast India: Sikkim (Oliver 1859).

Present status: Discovered from Sikkim by Oliver (1859). Though the species has also been reported from China, in India, the plants seem extremely rare, as further reports are scanty.

3.11. Utricularia striatula Sm.: Commonly known as striped bladderwort is a small insectivorous herb which is growing on wet rock or even on tree trunks.

Distribution in northeast India: Meghalaya, Nagaland, Sikkim (Lal et al. 2003; Lansdown et al. 2013). Present status: Least Concern (LC) ver 3.1.

3.12. Utricularia pubescens Sm.: A small to medium sized herbaceous annual plant growing on soil as well as on wet rocks.

Distribution in northeast India: Meghalaya (Rao \& Joseph 1967).

Present status: Reported only once from the area (v.s.). Seems to be rare, as it is known from only one more locality in India, i.e. Rajpur, near Dehradun (Saxena 1965).

3.13. Utricularia recta P. Taylor (U. scandens subsp. firmula (Oliver) Z. Yu Li): Small herb, growing in grassland as well as on rocks.

Distribution in northeast India: NE India (Li \& Cheek 2011).

Present status: Widespread in Africa and Asia. In India in the Himalayan part of Uttarakhand $(\mathrm{Ku}-$ maun), in Sikkim and in Meghalaya (Khasi Hills), and widespread in Nepal and Bhutan; in China only known from western Yunnan (Taylor 1989). 
3.14. Utricularia subulata L.: An annual to perennial terrestrial plant.

Distribution in northeast India: Jarain, Meghalaya (Joseph \& Mani 1982, misidentified as $U$. stanfieldii, an African species that is not known from India, $c f$. Taylor 1989).

Present status: Widespread and common in India.

3.15. Utricularia inflexa Forssk.: Medium to large sized suspended aquatic with a whorl of 5-10 floats near the base of the peduncle, corolla white with violet nerves.

Distribution in northeast India: Assam (Taylor 1989).

Present status: Widespread throughout India.

3.16. Utricularia stellaris L. f.: Medium to large sized suspended aquatic with a whorl of 3-8 floats above the middle of the peduncle, corolla yellow.

Distribution in northeast India: Meghalaya (Joseph \& Joseph 1986; Taylor 1989).

Present status: Widespread.

4. Pinguicula alpina L. (Lentibulariaceae): Also known as alpine butterwort, it is a small, herbaceous, perennial insectivore and has white personate spurred flowers, some with a yellow palate.

Distribution in northeast India: Sikkim (Singh \& Sanjappa 2011).

Present status: Widespread in alpine region of the Himalaya.

5. Aldrovanda vesiculosa L. (Droseraceae): A rare, monotypic, rootless, free floating aquatic carnivorous plant (floats just below the water surface).

Distribution in northeast India: Manipur- Imphal (Zaman et al. 2011).

Present status: Very rare in northeastern India and only once reported from Imphal by Deb in 1965 (Zaman et al. 2011) and since then it never have been collected there nor from other parts of India. The IUCN (IUCN 2013) listed the species as Endangered B2ab (iii, v) ver 3.1 (Cross 2012).

Acknowledgements: We are thankful to the Director of the Rain Forest Research Institute, Jorhat, Assam, for his encouragement. JS expresses his sincere thanks to Andreas Fleischmann for improving the manuscript.

\section{References}

Albert, V.A., Williams, S.E., and Chase, M.W. 1992. Carnivorous plants: phylogeny and structural evolution. Science 257: 1491-1495.

Anitha, K. 2011. Utricularia gibba. In: IUCN 2013. IUCN Red List of Threatened Species. Version 2013.2.

Anonymous. 1988. Wealth of India. Vol 3. Council of Scientific and Industrial Research (CSIR), New Delhi.

Parnell, J.A.N. 2005. An account of the Lentibulariaceae of Thailand. Thai Forest Bulletin (Botany) 33: 101-144.

Basak, R.K. 1975. Distribution of carnivorous plants in West Bengal. Bull. Bot. Surv. India 17: 97-107.

Bhowmik, S., and Datta, B.K. 2012a. Extended distribution of Utricularia bifida Linn. (Lentibulariaceae) from India. Researcher 4(3): 58-61.

Bhowmik, S., and Datta, B.K. 2012b. Utricularia caerulea L. (Lentibulariaceae) - A new record from Tripura, Northeast India. NeBIO 3(1): 35-38. 
Bhowmik, S., and Datta, B.K. 2013. Pollen morphology of some carnivorous plants from Tripura, India. J. Fundamental Applied Sci. 2(2): 36-38.

Bordoloi, R.P.M. 1977. The pitcher plant Nepenthes khasiana. Sreeguru Press, Guwahati, India. 59 pp.

Chew, M.Y., and Haron, N.W. 2011. Utricularia (Lentibulariaceae) habitat diversity in Peninsular Malaysia and its implications for conservation. Gardens' Bulletin Singapore 63(1 \& 2): 451-464.

Choosawad, D., Leggat, U., Dechusukhum, C., Phongdara, A., and Chotigeat, W. 2005. Anti-tumor activities of fucoidan from the aquatic plant Utricularia aurea Lour. Songklanakarin J. Sci. Technol. 27(Suppl. 3): 799-807.

Compton, H. 1909. The morphology and anatomy of Utricularia brachiata. The New Phytologist 4: 117-130.

Cross, A. 2012. Aldrovanda vesiculosa. In: IUCN 2013. IUCN Red List of Threatened Species. Version 2013.2.

Deb, D.B. 1983. The Flora of Tripura State, Vols. I \& II. Today \& Tomorrow's Printers and Publishers, New Delhi.

Didry, N., Dubreuil, L., Trotin, F., and Pinkas, M. 1998. Antimicrobial activity of aerial parts of Drosera peltata Smith on oral bacteria. Journal of Ethnopharmacology 60(1): 91-96.

Dixit, S., and Bera, S.K. 2012. Pollen rain studies in wetland environ of Assam, Northeast India, to interpret present and past vegetation. International Journal of Earth Sciences and Engineering 5(4): 739-747.

Ellison, A.M., and Gotelli, N.J. 2001. Evolutionary ecology of carnivorous plants. Trends Ecol. Evol. 16: 623-629.

Fleischmann, A. 2012. The new Utricularia species described since Peter Taylor's monograph. Carnivorous Plant Newsletter 41(2): 67-76.

Gibson, R., Conn, B.J., and Bruhl, J. 2012. Morphological evaluation of the Drosera peltata complex (Droseraceae). Australian Systematic Botany 25(1): 49-80.

Hazarika, S., and Barthakur, S.K. 2012. Hydrophytic flora of Assam - I. five new records. Pleione 6(2): 401-405.

IUCN. 2013. IUCN Red List of Threatened Species. Version 2013.2. http://www.iucnredlist.org, accessed 12 December 2013.

Jain, S.K., and Sastry, A.R.K. 1980. Threatened plants of India - a state-of-the-art report. Botanical Survey of India, Howrah.

Janarthanam, M.K., and Henry, A.N. 1992. Bladderworts of India. Botanical Survey of India, Calcutta.

Jayaram, K., and Prasad, M.N.V. 2006. Drosera indica L. and D. burmanii Vahl., medicinally important insectivorous plants in Andhra Pradesh-regional threats and conservation. Current Science 91: 943-946.

Jebb, M.H.P., and Cheek, M.R. 1997. A skeletal revision of Nepenthes (Nepenthaceae). Blumea 42(1): 1-106.

Joseph, J., and Joseph, K.M. 1986. Insectivorous plants of Khasi and Jaintia Hills, Meghalaya, India: A preliminary survey. Botanical Survey of India, Calcutta.

Joseph, J., and Mani, J. 1982. One new species and one new record from India in the genus Utricularia. Bull. Bot. Surv. India 24(1-4): 108-111.

Juniper, B.E., Robins, R.J., and Joel, D.M. 1989. The Carnivorous Plants. Academic Press, San Diego, California.

Kamble, M.V., Harikrishnan, S., and Balakumar, P. 2012. Utricularia caerulea (Lentibulariaceae): a 
new record to flora of Andaman \& Nicobar Islands. Rheedea 22(2): 116-118.

Kato,Y., Mochida, M., and Koike, H. 2006. The northernmost locality of Utricularia caerulea L.

(Lentibulariaceae) in Japan. The Journal of Japanese Botany 81(1): 41-43.

Köppen, W., and Geiger, G. (eds.) 1930-1939. Handbuch der Klimatologie. 5 vols., Borntraeger, Berlin.

Lal, J., Chaturvedi, S.K., and Shukla, B.K. 2003. Utricularia striatula Smith (Fam. Lentibulariaceae) from Nagaland. Abstract. 5th Indian Agricultural Scientists and Farmers' Congress, 1516 Feb. 2003, University of Allahabad, Bioved Research and Communication Centre, Allahabad, India.

Lansdown, R.V., Knees, S.G., and Patzelt, A. 2013. Utricularia striatula. In: IUCN 2013. IUCN Red List of Threatened Species. Version 2013.2.

Li, Z.Y., and Cheek, M.R. 2011. Lentibulariaceae. Flora of China 19: 480-491.

Majumdar, K., Datta, B.K., and Shankar, U. 2011. Community structure and population status of Drosera burmanii Vahl. with new distributional record in Tripura, India. Journal of Ecology and the Natural Environment 3(13): 410-414.

Mandal, A., and Mukherjee, A. 2011. Nepenthes khasiana: the pitcher plant needs attention for conservation. Current Science 100(6): 807.

Natarajan, K., Kottaimuthu, R., Balasubramanian, V., Pandian, P.A., Malaisamy, M., and Ponnuchamy, A. 2008. Note on the identity of carnivorous plants of Karungalakudi, Tamil Nadu, India. Ethnobotanical Leaflets 12: 1073-1077.

Oliver, D. 1859. III. The Indian species of Utricularia. J. Proc. Linn. Soc., Bot. 3: 170-190.

Panday, S., Sinha, B.K., and Karmakar, P. 2013. Three new additions for the state flora of Mizoram, India. Pleione 7(1): 266-269.

Parnell, J.A.N. 2005. An account of the Lentibulariaceae of Thailand. Thai Forest Bulletin (Botany) 33: 101-144.

Prasad, M.N.V., and Jeeva, S. 2009. Coal mining and its leachate are potential threats to Nepenthes khasiana Hook. f. (Nepenthaceae) that preys on insects - an endemic plant in North Eastern India. Biological Diversity and Conservation 2/3: 29-33.

Raju A., and Christina, A.J.M. 2013. Drosera burmannii Vahl.: Antioxidant potential in Dalton's Ascites Lymphoma (DAL) bearing mice. Journal of Medicinal Plant Studies 1(4): 152-159.

Rao, A.S., and Joseph, J. 1967. Utricularia pubescens Sm. - first report of its occurrence in India. Indian Forester 93: 32-33.

Rathore, T.S., Tandon, P., and Shekhawat, N.S. 1991. In vitro regeneration of pitcher plant (Nepenthes khasiana Hook. f.) - a rare insectivorous plant of India. J. Plant Physiol. 139: 246-248.

Rice, B.A. 2006. Growing Carnivorous Plants. Timber Press, Portland, USA.

Santapau, H., and Henry, A.N. 1976. A dictionary of the flowering plants in India. Publication and Information Directorate, New Delhi.

Saxena, H.O. 1965. Utricularia pubescens Sm. - a new record for India. Indian Forester 91: 73-75. Sharma, B.K. 2012. Phytoplankton diversity of a floodplain lake of the Brahmaputra River basin of Assam, north-east India. Indian J. Fish. 59(4): 131-139.

Singh, B., Phukan, S.J., Sinha, B.K., Singh, V.K., and Borthakur, S.K. 2011. Conservation strategies for Nepenthes khasiana in the Nokrek Biosphere Reserve of Garo hills, Northeast, India. International Journal of Conservation Science 2(1): 55-64.

Singh, P., and Sanjappa, M. 2011. Flowering plants of Sikkim - An analysis. In: Biodiversity of Sikkim - Exploring and Conserving a Global Hotspot. Arrawatia, M.L., and Tambe, S. (eds.). Department of Information and Public Relations, Government of Sikkim, Gangtok. pp. 65-88. 
Subramanyam, K., and Kamble, N. P. 1968. Chromosome numbers in certain Indian species of Utricularia L. (Lentibulariaceae). Proceedings of the Indian Academy of Sciences - Section B, 68(5): 221-224.

Suksathan, P., and Parnell, J.A.N. 2010. Three new species and two new records of Utricularia L. (Lentibulariaceae) from Northern Thailand. Thai For. Bull. (Bot.) 38: 23-32.

Takhtajan, A.L. 1986. Floristic Regions of the World. University of California Press, Berkeley and Los Angeles, California.

Taylor, P. 1989. The genus Utricularia - a taxonomic monograph. Kew Bulletin Additional Series XIV: London.

Venugopal, N., and Devi, N.R. 2003. Development of the anther in Nepenthes khasiana Hook.f. (Nepenthaceae), an endemic and endangered insectivorous plant of North East India. Feddes Repertorium 114(1-2): 69-73.

Venugopal, N., Devi, R.K., and Rao, C.S. 2007. An interesting observation on the mycorrhizal symbiosis in the insectivorous plant, Drosera peltata Sm. in Meghalaya, North-East India. Carnivorous Plant Newsletter 36(1): 9-13.

Wikipedia. 2013. http://en.wikipedia.org/wiki/List_of_Nepenthes_species, accessed 11 December 2013.

Yee, C.M., Rahman, R.A., and Haron, N.W. 2012. Micro-structure studies on Chirita and Utricularia of peninsular Malaysia. Pak. J. Bot. 44(6): 2063-2066.

Zaman, M., Naderuzzaman, A.T.M., Hasan, M., and Naz, S. 2011. Ecology, morphology and anatomy of Aldrovanda vesiculosa L. (Droseraceae) from Bangladesh. Bangladesh J. Bot. 40(1): $85-91$.

Zhuang, X. 2011a. Drosera peltata. In: IUCN 2013. IUCN Red List of Threatened Species. Version 2013.2.

Zhuang, X. 2011b. Utricularia bifida. In: IUCN 2013. IUCN Red List of Threatened Species. Version 2013.2

Ziemer, B. 2010. Exciting conservation news: The Rare Nepenthes Collection project! Carnivorous Plant Newsletter 39(3): 67.

\section{Carnivorous Plant Nursery \\ Promoting environmental stewardship through}

engaging educational materials and low-cost, high-quality carnivorous plants.

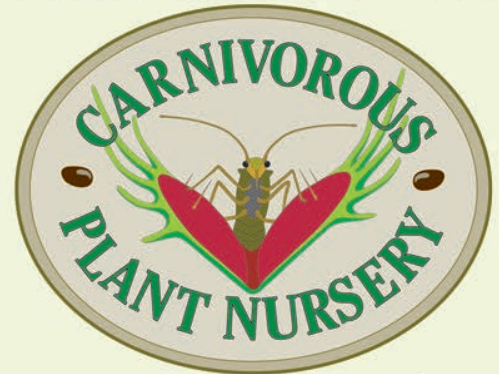

- Carnivorous Plants

- Bog Orchids, Bog Plants

- Live Wingless Fruitflies

- Activity Book for Carnivorous Plants

- Bugs in the Bog Board Game

- Free Monthly Drawing

- Online Shopping and Mail Order

\section{wWw.carnivorousplantnursery.com}

301-519-7505 | info@carnivorousplantnursery.com | 16128 Deer Lake Road, Derwood, MD 20855 